\title{
SPIRITUALITAS DAN PROACTIVE COPING PADA SURVIVOR BENCANA GEMPA BUMI DI BANTUL
}

\author{
Ardiman Adami \\ Rr. Indah Ria Sulistyorini \\ Universitras Istam indonesia
}

\begin{abstract}
The purpose of this reserach is to find comelation between spirituality and proactive coping among survivors of Bantul eathquake. Hypotheses proposed is that there's a pasitive correlation between spirituality and proactive coping among survivors.

Subjects were 92 residence of Bantul and who were survive of earthquake on last May 27 2006. Scales for measurement were proactive coping inventory (Greenglass, 2002) and Spintual Transedence Scale (Piedmont, 1999). Realiability of proactive inventory and spinitual transedence scale in order are 0.909 and 0.933 .

Data tested by Pearson's correlation product moment wia SPSS for windows. Result of the research showed that spirituality and proactive coping are having very significant correlation coefficients 0.741 ( $p=0.000$ ). It mean that spirituality influence the emergence of proactive coping among earthquake survivor.
\end{abstract}

Keyword: spirituality, proactive coping, earthquake survivo

\section{PENGANTAR}

Bencana gempa tektonik berkekuatan 5,9 skala Richter telah mengguncang Yogyakarta dan sekitamya, Sabtu (27/05/2006) pukul 05:53 WiB. Bencana ini merupakan peristiwa katastroplk dan traumatis teburuk yang pemah terjadi d Indonesia, setelah bencana gempa dan gelombang tsunami yang melanda Provinsi Aceh dan Sumatrera Utara df penghujung Desember 2004 yang menewaskan sekitar 170.000 jiwa (Kompas, 28/05/2006).

Gempa bumi yang terjadi di Yogyakarta kali ini telah menewaskan lebih dari 6.000 jiwa serta meluluhlantakkan ribuan bangunan, infrastruktur, dan memutuskan jaringan telekomunikasi di Kota Yogyakarta dan Kabupaten Bantul. Khusus wilayah Bantul, sebanyak 4.143 korban tewas dan 779.287 jwa lainnya harus tinggal d tendatenda pengungsian. Adapun kerusakan rumah warga yang ditimbukan oleh gempa adalah sebanyak 71.763 unit roboh, 71.372 unit rusak berat/sedang, serta 73.669 unit rusak ringan (http://www.portalinfaq.org).

Bencana tersebut menyisakan berbagai kondisi yang sangat memprihatinkan. Selain menderita luka fisik, para korban yang selamat (survivor) juga mengalami gangguan psikologis yang berdampak pada kondisi psikis dan spiritual mereka. Banyak analisis telah memaparkan berbagai hal tentang realitas bencana yang terjadi hingga rencana ke depan dalam membangun kembali daerah gempa dari keterpurukan. Upaya rehabilitasi tersebut, tentunya tidak lepas dari pemahaman yang kongkrit mengenai kondisi wilayah dan masyarakat yang meliputi kondisi prabencana dan pasca-bencana. Dalam hal ini, tentunya penting untuk diperhatikan pula bagaimana kondisi psikis dan spiritual masyarakat Yogyakarta, terutama mereka 
yang secara langsung menjadi korban bencana.

Penanganan stres pada survivor akibat gempa đi Yogyakarta memang tidak mudan. Pengalaman traumatis karena gempa telah menggoncangkan dan melemahkan pertahanan individu dalam menghadapi tantangan dan kesulitan hidup sehari-hari. Apalagi kondisi trauma, kondisi fisik dan mental, aspek kepribadlan masingmasing survivortidak sama.

Masyarakat yang menjadi survivor dari suatu bencana cenderung memiliki masalah penyesuaian perilaku dan emosional. Perubahan mendadak sering membawa dampak psikologis yang cukup berat. Beban yang dihadapi oleh survivor tersebut dapat mengubah pandangan mereka tentang kehidupan dan menyebabkan tekanan pada jwa mereka. Kejadian gempa di Yogyakarta menjadi beban dan tekanan tersendiri bagi para survivorkarena musibah ini baru pertama kali dialami oleh survivor dan merupakan kejadian yang tidak terduga sama sekali.

Bagi sebagian orang yang luput dari maut, menerima kenyataan bahwa dirinya telah kehilangan banyak hal akibat gempa adalah hal yang menyakitkan dan sulit diterima. Meski terasa lebih ringan karena bencana ini melanda banyak orang, namun perubahan yang begitu mendadak dan dianggap bernilai karena mencakup penghidupan selanjutnya, cukup sulit untuk diterima. Hal ini terthat pada beberapa survivor gempa yang belum bisa menerima kenyataan bahwa dirinya telah kehilangan rumah dan sanak keluarga. Mereka masin merasa bahwa segalanya baik-baik saja, sikap mudah tersinggung bila orang bertanya mengenai gempa atau kondisi dirinya setelah gempa terjadi, menjadi mudah marah akan hal-hal kecil, kehilangan semangat untuk hidup, dan menjadi terfalu pasrah akan kehidupan (fatalistik).

Ketika melakukan pendampingan psikologis kepada beberapa survivordi RSU PKU Muhammadiyah Yogyakarta (1820/06/2006), penulis bisa menyaksikan langsung kondisi mereka. Tidak sedikit survivor yang mengalami berbagai tekanan psikologis sekaligus rasa sakit yang mendalam. Kehilangan anggota keluarga telah membuat luka psikis yang dalam. Apalagi kejadiannya begitu mendadak dan mereka menyaksikan langsung anggota keluarga yang luka maupun meninggal. Kehilangan tempat tinggal juga merupakan pukulan telak. Mereka menyaksikan rumahnya yang dibangun dengan berbagai usaha hancur berantakan. Tak pelak kondisi ini menimbulkan beban psikis yang mendalam,

Munculnya gejala-gejala stres, seperti rasa takut, cemas, duka cita yang mendalam, tidak berdaya, putus asa, kehilangan kontrol, frustrasi sampal depresi bermuara pada kemampuan individu dalam memaknai suatu musibah secara lebih realistis. Gejala-gejala terse but adalah reaksi wajar dari pengalaman yang tidak wajar. Tentunya hal ini tidak bisa dibiarkan begitu saja. Mereka memerlukan cara yang tepat untuk mengatasi masalah yang dialami.

Dalam hal ini, konsep coping merupakan hal yang penting untuk dibicarakan. Konsep coping menunjuk pada berbagai upaya, baik mental maupun perilaku, untuk menguasai, mentoleransi, mengurangi, atau meminimalisasikan suatu situasi atau kejadian yang penuh tekaman. Dengan kata lain, coping merupakan suatu proses di mana individu berusaha untuk menangani dan menguasai situasi yang menekan akibat dari masalah yang sedang dihadapinya. Beragam cara dilakukan. Namun, semua bermuara pada perubahan kognitif maupun perilaku guna memperoleh rasa amandalamdirinya.

Ketika seseorang tertimpa suatu musibah, biasanya ia akan mendekat kepada Tuhan dengan meningkatkan ibadah dan perbuatan baik lainnya. Hal ini dipertihatkan oleh sebagian besar warga Bantul yang mengaku tawakal dengan memasrahkan segalanya kepada Tuhan. Mereka bersyukur masih diberi keselamatan, sehingga menjadikan mereka semakin dekat kepada Tuhan serta menyadari berbagai dosa dan kesalahan yang telah diperbuat selama Ini. Bencana gempa ditafsirkan sebagai peringatan keras Tuhan kepada manusia 
yang telah lama berkubang dalam dosa dan dusta (Maarif, 2006).

Survivor gempa yang tingkat spiritualitasnya tinggi akan menjadikan mereka senantiasa hidup dalam nuansa keimanan kepada Tuhan. Mereka akan memaknai aktivitasnya dalam kehidupan ini sebagai ibadah kepada Tuhan. Mereka pun akan semakin tegas dan konsisten dalam sikap dan langkah hidupnya serta semakin terikat dengan aturan Sang Pencipta dengan perasaan ridha dan tenteram. Perasaan itu akan menjadikannya kuat dalam menghadapi segala persoalan hidup. Mereka dapat mengambil hikmah atas musibah yang menimpanya, tidak putus asa, dan menjadikan hambatan-hambatan yang ditemul pasca-bencana sebagai tantangan untuk memulai kehidupan baru. Mereka menganggap bahwa bencana bukan akhir dari segala-galanya. Bencana dapat diubah menjadi suatu pengalaman positif yang memiliki makna.

Identitas spiritual dibutuhkan individu dalam mengkonstruksi makna atas pengalaman hidup. Dengan adanya kepercayaan pribadi untuk memberikan makna luar biasa kepada realitas kehidupan, agama akan mampu mengarahkan individu untuk memberikan penerimaan tulus atas musibah yang terjadi. Kondisi tersebut memungkinkan individu untuk memaknai kembali hidupnya dengan membuat perencanaan atas setiap kemungkinan yang terjadi setelah mengalami musibah untuk mencapai suatu tujuan tertentu pada masa yang akan datang.

Emmons (2000) mengungkapkan bahwa spiritualitas bermanfaat dalam upaya untuk memecahkan berbagai permasalahan dalam kehidupan. Spiritualitas dapat memprioritas-ulangkan tujuan-tujuan (reprioritization of goals). Terlebih lagi, pribadi yang spiritual lebih mudah menyesuaikan diri pada saat menangani kejadian-kejadian traumatis. Mereka pun lebih bisa menemukan makna dalam krisis traumatis dan memperoleh panduan untuk memutuskan hal-hal tepat apa saja yang harus dilakukan.

Sebuah penelitian yang dilakukan oleh Graham, dkk. (2001) menunjukkan bahwa semakin penting spiritualitas bagi seseorang. maka semakin besar kemampuannya mengatasi masalah yang dihadapi. Penelitian ini menyarankan bahwa spiritualitas dapat memiliki peran yang sangat penting dalam mengatasi stres. Spiritualitas dapat melibatkan sesuatu d luar sumber-sumber yang nyata atau mencari terapi untuk mengatasi situasi-situasi yang penuh tekanan d dalam hidup seseorang. Kesehatan spiritual mencakup penemuan makna dan tujuan dalam hidup seseorang; mengandalkan Tuhan atau suatu kekuatan yang lebih tinggi (The Higher Power), merasakan kedamaian, atau merasakan hubungan dengan alam semesta. Spika, Shaver, dan Kirkpatrick (Graham, dkk. 2001) mencatat tiga peran spiritualitas dalam proses coping, yaitu menawarkan makna kehidupan, memberikan sense of control terbesar dalam mengatasi situasi, dan membangun self esteem (harga diri). Oleh karena itu, spiritualitas pada individu cukup berperan dalam proactive coping karena tidak selamanya orang mampu menghadapi kesukaran yang menimpanya, dan tidak selamanya pula orang berhasil mencapai tujuan serta berhasil menghindarkan sesuatu yang tidak diinginkannya setelah mengalami suatu musibah.

\section{DASARTEORI}

\section{Proactive Coping}

Aspinwall dan Taylor (1997) mengungkapkan bahwa perilaku proaktif merupakan suatu proses di mana seseorang mengantisipasi penyebab stres yang berpotensi mengganggu keseimbangan emosinya dan bertindak dalam rangka mencegah hal tersebut terjadi dalam dirinya.

Menurut Schwarzer (Greenglass, 2001), proactive coping adalah suatu pencapaian tujuan menuju sikap mandiri dan perbaikan diri dengan berusaha merealisasikan tujuan tersebut melalui proses pengaturan diri untuk mencapai tujuan yang dinginkan dan menjelaskan apa yang memotivasi seseorang dalam mencapai tujuan tersebut, serta 
berkomitmen terhadap diri sendiri untuk memanajemen kualitas pribadi.

Sementara itu, Greenglass (2001) mendefinisikan proactive coping sebagai strategi coping yang multidimensional dan lebih banyak melihat pad a pencapaian tujuan akhir. Proactive coping memfokuskan pada perbaikan kualitas hidup (personal quality of Ifte management) dengan menggabungkan elemen-elemen psikologi positif. Lebih jauh menurut Greenglass, proactive coping mengintegrasikan proses dari kualitas personal dalam memanajemen kehidupan dengan pengaturan diri (self regulatory) untuk mencapai tujuan. Proactive coping ditunjukkan dengan tiga hal utama, yaitu:

a. Kemampuan untuk mengintegrasikan rencana dan strategi-strategi preventif dengan cara proaktif untuk pengaturan diri dalam rangka pencapaian tujuan.

b. Kemampuan untuk melakukan identifikasi dan menggunakan sumbersumber sosial (social resources) untuk mencapai tujuan secara proaktif.

c. Menggunakan penyelesaian masalah secara emosional dengan proaktif untuk pengaturan diri dalam rangka mencapai tujuan.

Berdasarkan penjelasan tersebut, dapat disimpulkan bahwa proactive coping merupakan suatu cara atau usaha bagaimana individu mampu mencapai tujuan yang hendak dicapai dengan mengintegrasikan kualitas personal seseorang dalam hal perencanaan, penentuan strategi-strategi preventif, dan identifikasi masalah dengan dukungan sosial, sikap optimis, serta kemampuan efikasi diri individu dalam melihat resiko, di mana tuntutan dan hambatan selama proses pencapaian tujuan sebagai sesuatu yang menantang dan bukan sebagai ancaman.

Sementara itu. Greeglass, Schwarzer, Jakubiec, Fiksenbaum, dan Taubert (Greenglass, 2001) mengungkapkan bahwa proactive coping terdiri dari enam aspek, yaitu:

a Proactive Coping. yakni mekanisme pengatasan masalah yang mengkombinasikan potensi kognitif dan perilaku individu untuk mencapai tujuan (goal attainment) dengan cara mengatur diri.

b. Reflective Coping, yakni mekanisme penanganan masalah yang mengacu pada ranah kognitif secara maksimal untuk berimajinasi ataupun melakukan refleksi atas pengalaman yang telah lalu berkaitan dengan pencarian solusi.

c. Strategic Planning, yakni strategi pengatasan masalah yang mernfokuskan pada proses pencapaian tujuan yang berorientasi pada aksi yang telah terjadwal dan telah disusun dengan cara memilah-milah masalah menjadi beberapa bagian masalah yang lebih kecil.

d. Preventive Coping, yakni strategi pengatasan masalah yang sifatnya mencegah segala bentuk kemungkinan buruk alau sumber stres yang sewaktuwaktu dapat menekannya.

e. Instrumental Support Soeking, yakni strategi pengatasan masalah yang memfokuskan pada masalah yang dihadapi dengan pencarian dukungan, informasi-inf ormasi yang ada, dan mendapatkan timbal balik dari orang lain ketika dalam keadaan lertekan atau dalam menghadapi masalah.

f. Emotional Support Seeking, yaknl strategi pengatasan masalah yang benpa pencarian dukungan emosional ketika dalam keadaan stres atau tertekan dengan lebih fokus untuk membangkitkan empati, dan mencari dukungan emosional dari orang-orang terdekat.

Greenglass (2002) membagi faktorfaktor yang mempengaruhi proactive coping yang dilakukan oleh individu menjadi dua bagian, yaitu faktor internal dan faktor ekstemal. Faktor internal meliputi self efficacy, yakni kepercayaan diri individu pada kemampuan yang dimilikinya untuk memberikan kontrol pada semua kejadian yang akan mempengaruhi hidupnya (Kazdin, 2002), dan optimisme, yakni kemampuan melihat sisi terang kehidupan dan memelihara sikap positif, sekalipun berada 
dalam kesulitan (Stein \& Book, 2004). Sedangkan faktor eksternal meliputi dukungan sosial (social support) dalam bentuk informasi yang diperoleh, pengalaman yang dialami oleh diri sendiri maupun orang lain, serta dukungan emosional dari orang lain.

\section{Spiritualitas}

Tuhan menciptakan manusia dengan segenap keunikan. Sejak ia dilahirkan, manusia memiliki potensi yang meliputi sisi psikologis, sosial, dan spiritual. Menurut Bastamian (1995), untuk dapat memahami manusia seutuhnya, baik dalam keadaan sehat maupun sakit, pendekatan yang digunakan mestinya tidak lagi memandang manusia sebagal makhluk bio-psiko-sosial (jasmani, psikologis, dan sosial), melainkan manusia sebagai makhluk bio-psiko-sosiospiritual (jasmani, psikologis, sosial, dan spiritual).

Istilah spiritualitas sudah jamak digunakan secara luas. Namun derrikian, istilah ini memiliki makna yang beragam, tergantung pada waktu, tempat, dan bldang keilmuan di mana istilah ini digunakan. Menurut Stoll (Emmons, 2000), deskripsi dari spiritualitas sangat beragam dan hampir tidak ada satu definisi yang disepakati bersama. Oleh karena itu, deflnisi spiritualitas tergantung pada perspektif apa yangdigunakan.

Secara terminologis, splritualitas berasal dari kata "spirit". Dalam literatur agama dan spiritualitas, istilah spirit memiliki dua makna substansial, yaitu:

a. Karakter dan inti dari jiwa"jiwa manusia, yang masing-masing saling berkaitan, serta pengalaman dari keterkaitan jiwajiwa tersebut yang merupakan dasar utama dari keyakinan spiritual. "Spirit" merupakan bagian terdalam dari jwa, dan sebagai alat komunikasi atau sarana yang memungkinkan manusia untuk berhubungan dengan Tuhan.

b. "Spirit" mengacu pada konsep bahwa semua "spirit" yang saling berkaitan merupakan bagian dari sebuah kesatuan (conciousness and intelfect) yang lebih besar (http//hww.wikipedia.com).
Spiritualitas merupakan sebuah bentuk multidimensi dan dinamis. Emmons (2000) mengatakan bahwa teralu sederhana untuk menganggap spiritualitas sebagai tingkah laku yang pasif dan statis yang dimiliki seseorang, atau perilaku yang terikat di dalamnya, seperti ritual“ritual. Dia memandang spiritualitas sebagai sebuah rangkaian keahlian (skills), kekayaan (resources), kekuatan (capacities), atau kemampuan “kemampuan (abilities) yang memungkinkan seseorang untuk bisa memecahkan masalah serta mencapai tujuan"tujuan di dalam kehidupan mereka sehari“hari. Berdasarkan alasan-alasan tersebut, Emmons berpendapat bahwa spiritualitas dapat dipahami sebagai sebuah bentuk dari kecerdasan.

Secara eksplisit, Piedmont (2001) memandang spiritualitas sebagai rangkaian karakteristik motivasional (motivational traif), kekuatan emosional umum yang mendorong, mengarahkan, dan memilih beragam tingkah laku individu. Lebih jauh, Piedmont (2001) mendefinisikan spiritualitas sebagal usaha individu untuk memahami sebuah makna yang luas akan pemaknaan pribadi dalam konteks kehidupan setelah mati (eschatologica). Hal ini berarti bahwa sebagai manusia, kita sepenuhnya sadar akan kematian (mortality). Dengan demikian, kita akan mencoba sekuat tenaga untuk membangun beberapa pemahaman akan tujuan dan pemaknaan akan hidup yang sedang kita jalani.

Lebih lanjut, Piedmont (2001) mengembangkan sebuah konsep spiritualitas yang disebutnya sebagai Spiritual Transcendence, yaitu kemampuan individu untuk berada di luar pemahaman dirinya akan waktu dan tempat, serta untuk melihat kehidupan dari perspektif yang lebih luas dan objektif. Perpektif transendensi terse but merupakan suatu perspektif di mana seseorang melihat satu kesatuan fundamental yang mendasari beragam kesimpulan akan alam semesta, Konsep ini terdiri atas tiga aspek, yaitu:

a. Prayer Fulfilment (pengamalan ibadah), yakni sebuah perasaan gembira dan bahagia yang disebabkan oleh 
keterlibatan diri dengan realitas transenden.

b. Universality(universalitas), yakni sebuah keyakinan akan kesatuan kehidupan alam semesta (nature of life) dengan dirinya.

c. Connectedness (keterkaitan), yakni sebuah keyakinan bahwa seseorang merupakan bagian dari realitas manusia yang lebih besar yang melampaui generasi dan kelompok tertentu.

Pembahasan tentang spiritualitas sering kali membawa para ahli untuk mencari konsep spiritualitas sebagai hal yang berbeda dengan religiusitas. Elkins, dkk. (Smith, 1994) mengatakan bahwa spiritualitas memiliki makna yang sangat luas karena mencakup keyakinan-keyakinan serta perwujudan-perwujudan, baik yang religius maupun yang bukan religius. Sementara Richards, dkk. (1999) menekankan pentingnya membuat perbedaan antara spritualitas dan religiusitas. Meskipun agama secara tradisi bersumber dari hal-hal di mana spiritualitas berkembang, namun sudah jamak untuk mencapal kesucian dalam hubungan seseorang melalui seni, puisi, atau alam.

Pendapat tentang perlunya membedakan spiritualitas dan religiusitas didukung secara empiris oleh penelitian Woods dan Ironson (1999). Mereka menemukan perbedaan antara orang spiritual dan orang yang religius. Subjek yang menyatakan dirinya sebagai seorang religius cenderung melihat sisi spiritualitasnya yang berhubungan dengan institusi, tradisi, dan tindakan-tindakan. Sedangkan subjek yang menyatakan diri mereka sebagai seorang spiritual memandang spiritualitas mereka sebagai alat untuk menjadi saling berkaitan dengan makna transenden. Spiritualitas kemudian digambarkan sebagai sebuah bentuk hubungan manusia dengan dimensi yang lebih tinggi (The Higher Power) dan Tuhan di dalam dirinya. Agama lebih merupakan sebuah sistem keyakinan dengan sekumpulan dogma religius.

\section{Hipotesis}

Berdasarkan telaah teoritis dan permasalahan di atas, maka hipotesis yang diajukan dalarn penelitian ini adalah ada hubungan positif antara spiritualitas dengan proactive coping pada survivor bencana gempa bumi di Bantul. Semakin tinggi tingkat spiritualitas survivor gempa, semakin tinggi proactive coping dilakukannya. Sebaliknya, semakin rendah tingkat spiritualitas survivor gempa, semaikin rendah proactive coping yang dilakukannya.

\section{METODE PENELITIAN}

Penelitian ini menggunakan spiritualitas sebagai variabel bebas dan proactive coping pada survivor gempa sebagai variabel tergantung. Spiritualitas merupakan usaha individu untuk memahami sebuah makna yang luas akan pemaknaan pribadi dalam konteks kehidupan setelah mati (eschatological). Hal ini berarti bahwa sebagai manusia, kita sepenuhnya sadar akan kematian (mortality) dan kemudian membangun beberapa pemahaman akan tujuan dan pemaknaan akan kehidupan yang sedang kita jalani (Piedmont, 2001). Penelitian ini ingin mengungkapkan tingkat spiritualitas survivor bencana gempa bumi di Bantul. Dalam hal ini, spiritualitas yang dimaksud adalah spiritualitas transendental, yakni spiritualitas yang berkaitan dengan nilai-nilai ketuhanan atau kepercayaan terhadap keberadaan Tuhan atau suatu kekuatan yang lebih tinggi (The Higher Power).

Untuk mengukur tingkat spiritualitas survivor bencana gempa bumi di Bantul, penulis merumuskan Skala Spiritualitas yang mengacu pada Spirilual Transcendence Scale yang dikembangkan oleh Piedmont (1999). Skala ini terdiri atas tiga aspek, yaitu prayer fulfilment (pengamalan ibadah), universality (universalitas). dan connectedness (keterkaitan). Semakin tinggi skor yang diperoleh, maka menunjukkan tingkat spiritualitas subjek tinggi. Sobaliknya, semakin rendah skor yang diperoleh, maka 
menunjukkan rendahnya tingkat spiritualitas subjek.

Hasil analisis ujicoba alat ukur terhadap Skala Spiritualitas diperoleh hasil 43 aitem dinyatakan sahih dari 58 item yang diujicobakan. Aitem yang sahih tersebut memiliki korelasi aitem-total yang bergerak dari 0,268 sampai 0,789 . sedangkan aitem yang gugur sebanyak 15 item adalah item yang memiliki korelasi item-total kurang dari 0,25 . Sementara itu, reliabilitas Skala Spirltualitas dapat diketahui dengan menggunakan teknik Aipha Cronbanch pada SPSS 12.0 for Windows. Koefisien reliabilitas proactive coping sebesar 0,933 . Hal tersebut menunjukkan tingkat konsistensi atau kepercayaan sebesar $93,3 \%$ dan menampakkan variasi error sebesar $6,7 \%$.

Sementara itu, proactive coping merupakan suatu proses yang dilakukan oleh seseorang untuk mencapai tujuan yang hendak dicapai dengan cara mengintegrasikan kualitas personal yang ada pada diri baik itu berupa kemampuan membuat suatu perencanaan strategis, kemampuan untuk mengantisipasi stres yang akan terjadi selama proses pencapaian tujuan tersebut, kemampuan untuk melakukan refleksi serta kemampuan untuk mencari dukungan dari lingkungannya, di mana kelika proses pencapaian tujuan tersebut individu menemui resiko atau sesuatu yang mengancam dirinya, individu melihatnya sebagai sesuatu atau hal yang menantang untuk dihadapi (Greenglas, 2001). Penelitian ini ingin mengungkap baik atau buruknya proactive coping yang dilakukan oleh survivorbencana gempa bumi diBantul.

Untuk mengungkap baik atau buruknya proactive coping yang dilakukan oleh survivorbencana gempa bumi di Bantul, penulis merumuskan Skala Proactive Coping pada Survivor Gempa yang mengacu pada Proactive Coping Inventory yang dikembangkan oleh Greenglass (2002). Skala ini terdiri atas enam aspek, yaitu proactive coping, reflective coping, strafegic planning, preventive coping, instrumental support seeking, dan emotional support seeking. Sernakin tinggi skor yang diperoleh, maka menunjukkan baiknya proactive coping yang dilakukan oleh subjek. Sebaliknya, semakin rendah skor yang diperoleh, maka menunjukkan buruknya proactive coping yang dilakukan oleh subjek.

Sementara itu, hasil analisis uj coba alat ukur terhadap Skala Proactive Coping pada SurvivorGempa diperoleh hasil 32 item dinyatakan sahih dari 68 aitem yang diujicobakan. Item yang sahih tersebut memiliki korelasi item-total yang bergerak dari 0,253 sampai 0,772. Sedangkan item yang gugur sebanyak 36 item adalah item yang memiliki korelasi item-total kurang dari 0,25 . Sementara itu, reliabilitas Skala Proactive Coping pada Survivor Gempa dapat diketahui dengan menggunakan teknik Alpha Cronbanch pada SPSS 12.0 for Windows. Koefisien rellabilitas proactive coping sebesar 0,909. Hal tersebut menunjukkan bahwa tingkat konsistensi atau kepercayaan sebesar $90,9 \%$ dan menampakkan variasi error sebesar $9,1 \%$

Subjek penelitian yang berpartisipasi dalam penelitian ini adalah warga Bantul yang mengalami peristiwa bencana gempa bumi. Dalam proses penelitian, subjek yang digunakan berdomisiti of tujuh pedukuhan di Kabupaten Bantul, Yogyakarta, yaitu: Dusun Blunyahan, Desa Pendowoharjo, Kecamatan Sewon (19 orang), Dusun Ngentak, Desa Wijirejo, Kecamatan Pandak (10 orang), Dusun Prayan, Desa Srimulyo, Kecamatan Piyungan (8 orang), Desa Priyan, Kecamatan Trirenggo (16 orang), Dusun Plebengan, Desa Sidomulyo, Kecamatan Bambanglipuro (19 orang), Dusun Turi, Desa Sidomulyo, Kecamatan Bambanglipuro (8 orang), Desa Karanggayam, Kecamatan Bantul (12 orang). Dengan demikian, jumlah subjek dalam penelitian ini adalah 92 orang.

Data yang dihasilkan dalam penelitian ini dianalisis dengan menggunakan teknik product moment dari Pearson. Proses analisis menggunakan program SPSS 12.0 for Windows. 


\section{HASIL PENELITIAN}

1. Hasil Deskripsi Variabel Penelitian

\begin{tabular}{lcccc}
\hline Variabel & Rerata & Standar & Rerata & Kategorisasi \\
\hline Empink & Deviasi & Hipotetik & \\
\hline Proactivalitas & 131,5 & 21,5 & 107,5 & Tinggi \\
Proping & 92 & 16 & 80 & Tinggi \\
\hline
\end{tabular}

Melihat hasil yang tertera dalam tabel di atas, tampak bahwa pada kedua variabel penelitian, kondisi subjek penelitian berada dalam kategori tinggi, yakni dalam hal tingkat spiritualilas dan proactive coping.

2. Hasil Uji Hipotesis

Hasil analisis data menunjukkan bahwa antara spiritualitas dan proactive coping pada survivor gempa diperoleh koefisien korelasi $r_{x y}=0,741$ dengan $p=$ 0,000 ( $p<0,01$ ). Hal tersebut menunjukkan bahwa terdapat hubungan positif yang sangat signifikan antara spiritualitas dan proactive coping pada survivor bencana gempa bumi di Bantul. Semakin tinggi spiritualitas survivor gempa, semakin tinggi proactive coping yang dilakukannya. Sebaliknya, semakin rendah spiritualitas survivor gempa, semakin rendah proactive coping yang dilakukannya.

\section{PEMBAHASAN}

Berdasarkan hasil analisis data yang diperoleh dari lapangan, tertihat bahwa terdapat korelasi yang sangat signifikan antara variabel spiritualitas dan proactive coping pada survivor gempa $\left(r_{x y}=0,741\right)$. Hubungan positif ini menunjukkan bahwa semakin tinggi spiritualitas survivor gempa, semakin baik proactive coping yang dilakukannya. Sebaliknya, semakin rendah spiritualitas survivor gempa, semakin buruk proactive coping yang dilakukannya.

Dari hasil wawancara dan observasi lapangan, diperoleh data bahwa dalam menghadapi situasi yang sulit setelah gempa terjadi, para survivor memiliki keinginan kuat untuk mendekat kepada Tuhan dengan meningkatkan ibadah dan perbuatan baik lainnya. Hal ini diperlihatkan oleh sebagian besar rakyat Bantul yang mengaku tawakal dengan memasrahkan segalanya kepada Tuhan. Mereka bersyukur masih diberi keselamatan, sehingga menjadikan mereka semakin dekat kepada Tuhan serta menyadari berbagai dosa dan kesalahan yang telah diperuat selama ini. Bencana gempa ditafsirkan sebagai peringatan keras Tuhan kepada manusia yang telah lama berkubang dalam dosa dan dusta. Hal ini sesuai dengan konsep prayer fulfilment (pengamalan ibadah), yaitu sebuah perasaan gembira dan bahagia yang disebabkan oleh keterlibatan diri dengan realitas transenden (Piedmont, 2001), di mana para korban berusaha mencari rasa tenang dan tentram sebagai efek dari mengenal Tuhannya. Sikap tersebut dikuti dengan kepasrahan dan lawakal kepada Tuhan. Kepasrahan inilah yang akan mengarahkan individu kepada penerimaan akan kondisi kehidupannya, sehingga individu mampu bangkit dari keterpurukan untuk memulai lagi kehidupannya. Keyakinan ini akan mendorong individu untuk berusaha semaksimal mungkin dan membuat perencanaan strategis dengan harapan akan memberikan kemungkinan hasil akhir yang terbaik.

Universality dapat dilihat dari interaksi positif antara individu dan alam sekitamya, terutama sebelum dan sesudah terjadinya musibah. Termasuk meyakinl kekuasaan Tuhan terhadap alam semesta. Tingkat universality yang tinggi tampak pada perilaku individu dalam menjaga keseimbangan alam untuk meminimalkan kemungkinan terjadi musibah. Selain itu, individu meyakini bahwa bencana alam yang terjadi merupakan ketentuan dari Sang Pencipta. Individu juga mampu membaca fenomena alam untuk mengantisipasi datangnya musibah pado masa yang akan 
datang, sehingga tidak menimbulkan penderitaan dan kerugian yang lebih besar.

Sedangkan connectedness tampak pada pola interaksi interpersonal antara individu dengan orang lain, termasuk keluarga. Tingkat connectedness yang tinggi ditunjukkan melalui sikap meringankan penderitaan orang lain dan tidak mementingkan kepentingan diri sendiri (individualistik). Dalam suatu musibah, transaksi interpersonal blasanya diwujudkan dalam bentuk dukungan sosial berupa nasehat atau masukan, pemberlan Informasi, maupun dukungan emosiona! untuk memelihara keadaan psikologis Individu yang mengalami tekanan. Apabila individu memperoleh dukungan sosia! yang tinggi, maka ia akan mengalami hal yang positif dalam hidupnya, mempunyal harga diri yang lebih tinggi, dan mempunyai pandangan yang lebih optimistis terhadap kehidupannya.

Survivor gempa yang tingkat spiritualitasnya tinggi akan mengantarkan mereka senantiasa hidup dalam nuansa keimanan kepada Tuhan. Mereka akan memaknal aktivitasnya dalam kehidupan ini sebagal ibadah kepada Tuhan. Mereka pun akan semakin tegas dan konsisten dalam sikap dan langkah hidupnya serta semakin terikat dengan aturan Sang Pencipta dengan perasaan ridha dan tenteram. Perasaan itu akan menjadikan mereka kuat dalam menghadapi segala persoalan hidup. Mereka dapat mengambil hikmah atas musibah yang menimpanya, tidak putus asa, dan menjadikan hambatan-hambatan yang ditemui pasca-bencana sebagai tantangan untuk memulai kehidupan baru. Mereka menganggap bahwa bencana bukan akhir dari segala-galanya. Bencana dapat diubah menjadi suatu pengalaman positif yang memiliki makna bagi kehidupan yang akan datang.

Hal tersebut menguatkan penelitian sebelumnya yang dilakukan oleh Graham, dkk. (2001) yang menunjukkan bahwa semakin penting spiritualitas bagi seseorang. maka semakin besar kemampuannya mengatasi masalah yang dihadapi. Penelitian ini menyarankan bahwa spiritualitas bisa memiliki peran yang sangat penting dalam mengatasi masalah. Spiritualitas bisa melibatkan sesuatu d luar sumber-sumber yang nyata atau mencari terapi untuk mengatasi situasi-situasi yang penuh tekanan di dalam hidup seseorang. Kesehatan spiritual mencakup penemuan makna dan tujuan dalam hidup seseorang; mengandalkan Tuhan atau suatu kekuatan yang lebih tinggi (The Higher Power), merasakan kedamaian, atau merasakan hubungan dengan alam semesta.

Hasil penelitian ini jug a menunjukkan bahwa sumbangan efektif yang diberikan spiritualitas terhadap efektivitas proactive coping pada survivor gempa adalah sebesar $54,9 \%(R$ Squared $=0,549)$. Persentase tersebut menunjukkan bahwa pengaruh spiritualitas terhadap proactive coping pada survivor gempa tergolong tinggi. Sedangkan sisanya $45,1 \%$ dipengaruhi oleh faktor-faktor lain, seperti optimisme, kepercayaan terhadap kemampuan sendiri (self efficacy). dan dukungan sosial.

Bagi para survivor gempa, berbagai bentuk proactive coping ini akan memberikan penerimaan yang tulus atas musibah yang dialami, mengurangi kesedihan dan tekanan psikologis, membantu dalam menemukan makna positif dari pengalaman dan kehidupannya pasca-bencana, serta meningkatkan keimanan kepada kekuasaan Tuhan, di mana pada saat bersamaan dapat meningkatkan spiritualitas dalam diri mereka. Makna yang diresapi dari usaha-usaha proactive coping inl akan lebih memudahkan individu menerima apa yang terjadi pada dirinya, sehingga akan mendorong individu untuk mencapai suatu tujuan hidup yang lebih bermakna.

\section{PENUTUP}

Berdasarkan hasil penelitian yang telah dilakukan, maka dapatdisimpulkan halhal sebagai berikut:

1. Ada hubungan positif yang sangat signifikan antara spiritualitas dengan proactive coping pada survivor bencana gempa bumi di Bantul. Semakin tinggi tingkat spiritualitas survivor gempa, maka semakin tinggi pula proactive 
coping yang dilakukannya. Sebaliknya, semakin rendah tingkat spiritualitas survivor gempa, maka semakin rendah pula proactive coping yang dilakukannya.

2. Subjek dalam penelitian ini memiliki tingkat spiritualitas yang tinggi dan proactive coping yang tinggi pula.

Setelah mencermati hasil penelitian tersebut, peneliti mencoba untuk memberikan beberapa saran sebagai berikut:

1. Bagi SurvivorBencana Gempa Bumi

Penelitian ini menunjukkan bahwa subjek memiliki tingkat spiritualitas yang tinggi. Tingkat spiritualitas tersebut dapat mempengaruhi proactive coping yang dilakukan, sehingga mereka akan mampu mengatasi masalah yang dihadapi untuk mencapai kehidupan yang lebih bermakna. Secara kongkrit, beberapa hal yang perlu dipertahankan atau bahkan ditingkatkan, yaitu: (a) mengamalkan ibadah dengan ikhlas untuk memperoleh kekuatan dan ketenangan sebagai media pendekatkan diri kepada Tuhan, (b) senantiasa berdoa dan tawakal kepada Tuhan dalam keadaan apapun, (c) mengambil hikmah atas musibah yang dialami, (d) meyakini takdir Tuhan atas setiap musibah yang terjadi, dan (e) menjaga interaksi yang positif dengan orang lain dan alam sekitar.

2. Bagi Para Relawan dan Konselor Survivor Gempa

Peran para relawan, pembimbing, dan konselor dirasa sangat penting dalam menangani masalah-masalah psikologis yang dialami oleh para survivorgempa dalam bentuk dukungan emosional. Dukungan tersebut berperan penting dalam memelihara keadaan psikologis para survivor gempa yang mengalami tekanan. Keberadaan mereka membuat para survivor gempa merasa lebih diperhatikan, bemilai, dan dicintai

Kehidupan masyarakat Bantul yang kental dengan nilai-nilai religius mengharuskan para relawan dan konselor untuk membekali diri dengan pengetahuan agama secara memadai, sehingga mereka tidak kaku dalam mengarahkan para survivor gempa untuk lebih meningkatkan keimanan dan ketakwaannya kepada Tuhan dalam menghadapi musibah yang terjadi. Bila diperiukan, para relawan dan konselor dibekali kemampuan untuk melakukan terapi psikospiritual (Adz-Dzakiey, 2004).

Terapi ini mencakup tiga tahapan, yaitu tahapan penyadaran diri (self awareness), tahapan penyucian dan pengenalan citra diri (self identification), dan tahapan pengembangan diri (self development). Terapi ini akan memberikan penerimaan yang tulus atas musibah, mengurangi kesedihan dan tekanan psikologis, serta membantu para survivor gempa dalam menemukan makna positif dari pengalaman dan kehidupannya.

3. Bagi Pejabat Pemerintahan dan Tokon Masyarakat Setempat

Hendaknya para pejabat pemerintahan mulai dari tingkat pedukuhan sampai kabupaten bahkan provinsi, dan tokoh-tokoh masyarakat setempat untuk dapat mempertahankan tradisi keagamaan dalam masyarakat yang sudah ada selama ini, serta mendukung kegiatan keagamaan yang ada di masyarakat dalam rangka peningkatan nilai-nilai spiritualitas masyarakat setempat. Intemalisasi nilai-nilai spiritualitas yang kuat pada masyarakat merupakan potensi besar dan kuat dalam upaya pengatasan masalah pasca-bencana gempa bumi yang telah dibuktikan secara empirik

4. Bagi Peneliti Selanjutnya

Untuk penelitian selanjutnya, perlu lebih mencermati metode dan proses pengambilan data. Peneliti perlu terlibat langsung mendampingi para subjek dalam menjaw ab angket yang disediakan, sehingga jawaban yang mereka berikan sesuai dengan keadaan mereka yang sesungguhnya. Penelitian ke depan diharapkan mampu memahami konstruksi dalam mengembangkan alat ukur yang telah ada, serta memfokuskan pada pertuasan konsep pada masing-masing variabel, sehingga alat ukur yang dibuat benar-benar mewakili aspek untuk mengungkap hal yang akan diungkap.

Bagi peneliti lain yang tertarik untuk meneliti tema yang sama disarankan untuk 
mempertimbangkan variabel lain yang berhubungan dengan proactive coping pada survivor gempa, sehingga dapat ditentukan faktor-faktor lain yang juga mempengaruhi proactive copirgpada survivorgempa.

\section{DAFTAR PUSTAKA}

Adz-Dzakiey, M. H. B. 2004. Konseling dan Psikoterapi Islam: Penerapan Metode Sufistik. Edisi Revisi. Yogyakarta: Fajar Pustaka Baru.

Anonim. 2006. 12.000 Orang Butuh Penanganan Psikorogis Jangka Waktu Lama. http:/la11.ugm.ac.id/ (Diakses tanggal 20/06/2006).

Anonim. 2006. Kabar Jogja Hari Ini. http://www.portalinfaq.org/ (Diakses tanggal $20 / 06 / 2006$ ).

Aspinwall, L. G. \& Taylor, S. E. 1997. SelfRegulation and Proactive Coping. Psychological Bulletin, 121 (3): 417 436.

Baslaman, H. D. 1997. Integrasi Psikologi dengan Islam: Menuju Psikologi Islami. Editor: Fuad Nashori. Yogyakarta: Pustaka Pelajar \& Yayasan insan Kamil.

Emmons, R A 2000. Is Spirituality an Intelligence? Molivation, Cognition, and the Psychology of Ultimate Concern. Intemational Journal for The Psychology, 10(1).

Graham, S., Furr, S., Flowers, C. \& Burke, M. T. 2001. Religion and Spirituality in Coping with Stress. Journal of Counseling and Values, 46.

Greenglass, E. R. 2001. Proacive Coping. Work Stress and Bumout. Stress News, 13(2):1-4.

Greenglass, E. R. 2002. Chapter 3: Proactive Coping. Dalam E. Frydenberg (Ed.), Beyond Coping: Meeting Goa/s, Visions and Challenges (hal. 37-62). London: Oxford University Press.
Kazdin, A. F. (Ed.). 2000. Encydopedia of Psychology, Volume 7. American Psychological Assosiation: Oxford University Press.

Maarif, S. 2006. Musibah. Majalah Berita Mingguan Gatra. Edisi 14 Juni 2006.

Muluk, H. 2005. Aceh Pasca-Tsunami. Majalah Berita Mingguan Gatra. Edisi 45Januari2005

Piedmont, R. L. 2001 . Spiritual Transcendence and the Sclentific Study of Spirituality. Journal of Rehabilitation, 67 (1): 4-14.

Richards, T. A dkk 1999. Spiritual Aspects of Loss Among Partners of Men with AIDS: Post Bereavement Follow-Up. Death Study, 23: 105-107.

Shin, M., Rosano, M., Morch, H. \& Chestnut, D. E. 1984. Coping With Job Stress and Burnout in the Human Services. Joumal of Personality and Social Psychology, 46 (4), 864-876.

Smith, D. W. 1994. Theory of Spirituality. Jou ma l of Holistic Nursing, 9.

Stein, S. J. \& Book, H. E. 2004. Ledakan EQ: 15 Prinsip Dasar Kecerdasan Emosional Meraih Sukses. Bandung: Kaifa.

Taylor, S. 1995. Health Psychology. $3^{\text {rd }}$ ed. NewYork: McGraw-Hill, Inc.

Wikipedia, The Free Encyclopedia. $s p i r$ i $t u$ a $i$ i $t y$. http://en.wikipedia.org/w/index.php?tit le=Template:spirituality \&action=edit (Diakses tanggal 25/06/2006).

Woods, T. E \& Ironson, G. H. 1999. Religion and Spirituality in the Face of liness: How Cancer, Cardias, and HIV Patients Describe Their Spirituality/Religiosity. Journal of Health Psychology, 4: 393-412. 